\title{
Hepatic progenitors for liver disease: current position
}

This article was published in the following Dove Press journal:

Stem Cells and Cloning:Advances and Applications

24 February 2010

Number of times this article has been viewed

\author{
Alice Conigliaro' \\ David A Brenner ${ }^{2}$ \\ Tatiana Kisseleva ${ }^{2}$ \\ 'University "La Sapienza", \\ Dipartimento di Biotecnologie \\ Cellulari ed Ematologia Policlinico \\ Umberto I,V Clinica Medica, Rome, \\ Italy; ${ }^{2}$ Department of Medicine, \\ University of California, San Diego, \\ La Jolla, CA, USA
}

\begin{abstract}
Liver regeneration restores the original functionality of hepatocytes and cholangiocytes in response to injury. It is regulated on several levels, with different cellular populations contributing to this process, eg, hepatocytes, liver precursor cells, intrahepatic stem cells. In response to injury, mature hepatocytes have the capability to proliferate and give rise to new hepatocytes and cholangiocytes. Meanwhile, liver precursor cells (oval cells) have become the most recognized bipotential precursor cells in the damaged liver. They rapidly proliferate, change their cellular composition, and differentiate into hepatocytes and cholangiocytes to compensate for the cellular loss and maintain liver homeostasis. There is a growing body of evidence that oval cells originate from the intrahepatic stem cell(s), which in turn give(s) rise to epithelial, including oval cells, and/or other hepatic cells of nonepithelial origin. Since there is a close relationship between the liver and hematopoiesis, bone marrow derived cells can also contribute to liver regeneration by the fusion of myeloid cells with damaged hepatocytes, or differentiation of mesenchymal stem cells into hepatocyte-like cells. The current review discusses the contribution of different cells to liver regeneration and their characteristics.
\end{abstract}

Keywords: hepatic progenitor, liver disease, liver precursor cells, oval cells, hepatocytes, intrahepatic stem cells, cholangiocytes

\section{Cells contributing to liver regeneration}

It is believed that the ancient myth of Prometheus describes the capability of the liver to restore its mass. Punished by Zeus for the theft of fire, Prometheus, a Titan, was chained for eternity to a rock in the Caucasus; each day an eagle would eat his liver and each night the liver would regenerate only for the eagle to return the following day.

Liver regulates different functions during growth, development and adulthood. It serves as the first site of embryonic hematopoiesis, but turns into a vital detoxifying system in the postnatal period. In addition, liver serves as a major storage of glycogen and vitamin A, and remains the only organ in the adult organism capable of self renewal. ${ }^{1}$ Liver regeneration is a rapid and tightly orchestrated process that efficiently and precisely restores the original cellular mass and functionality of hepatocytes and cholangiocytes. It is regulated on several levels, with different cellular populations contributing to liver regeneration. First, mature hepatocytes (in contrast to mature hematopoietic cells) possess the ability to proliferate and repopulate the damaged liver (Figure 1). Some studies suggest that hepatocytes can give rise not only to new hepatocytes, but can also differentiate into cholangiocytes, suggesting that hepatocytes are bipotential cells, which possess stem cell-like features. Second, liver precursor cells (oval cells) differ from other cells in the liver by their ability to extensively proliferate, migrate in a specific zone (lobule) and 


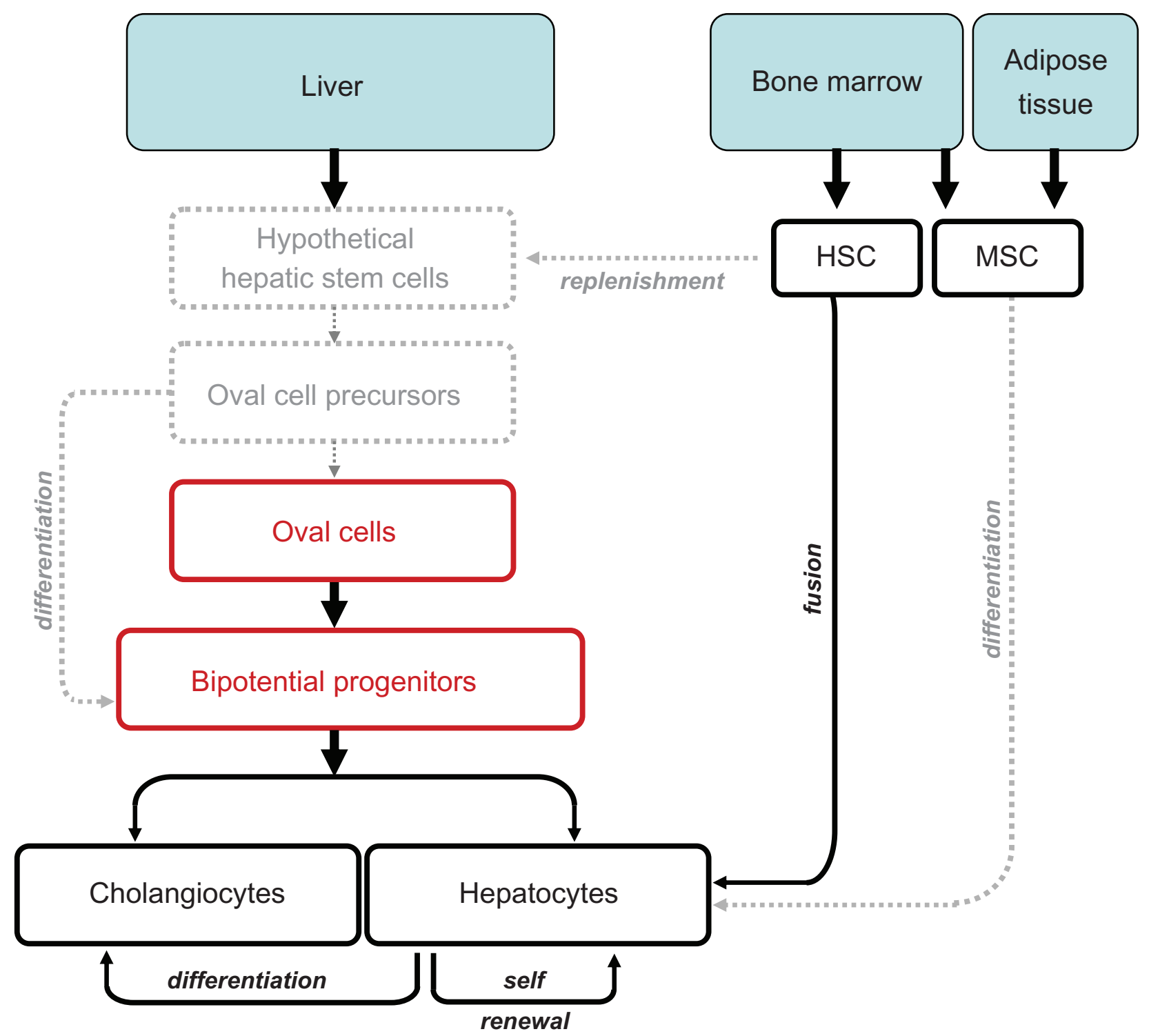

Figure I Cells contributing to liver regeneration.

Notes: Different cellular types regulate liver regeneration on several levels. Contribution of mature hepatocytes to regeneration of hepatic parenchymal cells is shown in black. Liver precursor cells with bipotential differentiation capacity are shown in red. Proposed pathways of liver regeneration, which require further clarification, are shown in grey. Abbreviations: HSC, hepatic stem cells; MSC, mesenchymal stem cells.

differentiate into hepatocytes and cholangiocytes. The concept of "liver precursor cells" has not been widely accepted until the last decade, most likely due to the established and recognized regenerative potential of hepatocytes. A population of small portal cells with ovoid nuclei and high nuclear/cytoplasmic ratio, named oval cells, was first identified in 1978 by Shinozuka and colleagues ${ }^{2,3}$ Since then, oval cells have become the most recognized precursor cells in the liver. The term "oval cells" is widely used to characterize a heterogeneous population of bipotential transient amplifying cells originating in the Canal of Hering, and activated in the liver as a result of injury or insult. ${ }^{4-6}$ The number of quiescent (or dormant) oval cells is very low under physiological conditions, but in response to an abruptly changing microenvironment, oval cells rapidly proliferate, change their morphology, surface markers and cellular composition, and differentiate to compensate for the cellular loss to maintain liver homeostasis. ${ }^{7}$ Third, since oval cells represent a mixed precursor population, they most likely differentiate from the "hypothetical true" intrahepatic stem cell(s). ${ }^{5,8,9}$ Here we call the intrahepatic stem cell hypothetical because it has not been well defined, but the growing evidence suggests its existence. Hypothetical intrahepatic stem cell(s) can, therefore, give rise to oval cells, causing their heterogeneity and/or other hepatic cells of non-epithelial origin. ${ }^{9}$ Fourth, since there is a close relationship between the liver and hematopoiesis, the contribution of bone marrow (BM) 
derived cells to liver regeneration has to be considered. Early studies proposed that hematopoetic cells can contribute to the replenishment of hepatic stem cells and oval cells. ${ }^{10,11}$ However, under most circumstances, reconstitution of the liver with BM cells results from fusion of damaged hepatocytes with myeloid cells. ${ }^{12}$ Furthermore, mesenchymal stem cells derived from the bone marrow or adipose tissues have a capacity to improve liver function, perhaps by giving rise to hepatocyte-like cells. ${ }^{13,14}$ Thus, we cannot exclude that circulating (hematopoietic and/or mesenchymal) stem cells cannot ameliorate the intrahepatic stem cells in response to severe injury.

\section{Hepatocytes}

In normal adult liver, mature hepatocytes exhibit quiescent phenotype, stay in the G0 phase of the cell cycle, and show minimal turnover. However, upon hepatocyte loss (such as shock liver, liver infection or surgical resection), these mature hepatocytes undergo cell division, while maintaining their metabolic function. ${ }^{15-18}$ The most widely used model to study hepatocyte transplantation, proliferation and reconstitution potential is the fumaryl-aceto-acetate hydrolase (FAH) knockout mice, in which the metabolic disorder causes extensive, continuous liver injury. In this murine model for the human disease, hereditary tyrosinemia type 1, donor hepatocytes expressing the FAH protein have a strong selective growth advantage over the recipient hepatocytes. ${ }^{12,19}$ Hepatocyte repopulation in wild type mice or $\mathrm{FAH}^{-/-}$mice is very rare. However, high efficiency of hepatocyte repopulation in $\mathrm{FAH}^{-/-}$mice is achieved only through massive selection pressure, caused by withdrawal of the protective drug 2-(2-nitro-4-trifluoromethylbenzoyl)-1,3-cyclohexanedione (NTBC) from drinking water, which results in severe loss of hepatocytes. Therefore the normal lobular structure and liver functions of $\mathrm{FAH}^{-/}$mice can be totally restored by transplantation of wild type hepatocytes. ${ }^{18,19}$ This model has demonstrated that normal adult hepatocytes can be serially transplanted through seven generations of mice, and that single hepatocytes can be clonally amplified like stem cells, and serially passaged to repopulate the $\mathrm{FAH}^{-/-}$mouse liver. ${ }^{20}$ As liver reconstituting cells, mature hepatocytes have the capacity to reconstitute almost $70 \%$ of livers in $\mathrm{FAH}^{-/}$mice. ${ }^{20}$ Successful transplantation of hepatocytes in mice encourage generation of "humanized" mouse models of liver disease. These models serve as a useful tool to study the physiology of human hepatocytes in mammalian organisms (versus in vitro), and further advance drug development for liver therapy. Several genetically manipulated mice have been successfully used for this purpose. Thus, human hepatocytes, obtained from patients after liver transplantation or by liver biopsies, were transferred into immunodeficient transgenics $A l b-u P A(\operatorname{tg}(+/-))$ that express uroplasminogen activator (uPA) under the transcriptional control of an albumin promoter. ${ }^{21,22}$ Another mouse model, $\mathrm{Rag}^{-/-} / \mathrm{Il}^{2} \mathrm{rg}^{-/-}$mice (immunodeficient for recombinant activation gene- 2 and the common $\gamma$-chain of the interleukin receptor mice), which are devoid of T and B cells, have been reported to be excellent recipients of human hematopoietic xenografts. ${ }^{23}$ High efficiency of liver repopulation with human hepatocytes can be achieved when $\operatorname{Rag}^{-/-} / I 12 \mathrm{rg}^{-/}$are crossed with $A l b-u P A(\operatorname{tg}(+/-))$ mice. ${ }^{24}$ Finally, generation of mice triple mutant for Fah, Rag2 and Il2rg can be efficiently repopulated with human hepatocytes. ${ }^{25}$

The stem like properties of differentiating hepatocytes have encouraged development of protocols for hepatocyte transplantation in patients, a procedure which is an appealing alternative to auxiliary orthotropic liver transplantation. Hepatocyte transplantation has been used in attempts to treat genetic diseases, including familial hypercholesterolemia, Crigler-Najjar syndrome type I, glycogen storage disease type 1a, urea cycle defects and congenital deficiency of coagulation factor VII. ${ }^{26,27}$ So far, hepatocyte transplantation in humans has yielded only early but not sustained success rates. Problems such as appropriate number of donor hepatocytes for transplantation, rejection of transferred hepatocytes, localization of the engrafted cells, and hepatocyte activity are currently unresolved and require further investigation. Moreover, human adult liver cells are often not available in sufficient numbers for successful repopulation of the donor liver. Human hepatocytes are difficult to maintain in culture. They do not multiply long term in vitro and also do not tolerate cryopreservation well. Alternative resources for cell transplantation could be bipotential liver precursor cells, mesenchymal stem cells, embryonic stem cells (ESC), or inducible pluripotential cells (iPS), expanded and differentiated in vitro into hepatocyte-like cells.

\section{Liver precursor cells (oval cells)}

Extensive or chronic liver damage, or prolonged intoxication and viral infection results in hepatocyte senescence, when mature hepatocyte proliferation is exhausted and suppressed. ${ }^{28,29}$ In this case, liver regeneration is carried out by a heterogeneous population of progenitor cells, located within (or immediately adjacent to) the canal of Hering, which become activated and proliferate to replace the impaired hepatic parenchyma. ${ }^{4}$ These cells were first described by E Faber in 1956 as "small oval cells with scant lightly basophilic cytoplasm and pale blue-staining 
nuclei" with a high nuclear/cytoplasmic ratio and an ovoid nucleus, and were called "oval cells". ${ }^{6}$

Oval cells represent a bipotential precursor population, which can simultaneously co-express epithelial markers typical for cholangiocytes (CK-7, CK-19, and OV-6) and hepatocytes (alpha-fetoprotein and albumin), suggesting the close relationship of oval cells to differentiated liver parenchymal cells. ${ }^{30,31}$ Experiments tracing the transfer of ${ }^{3} \mathrm{H}$ in thymidine-labeled oval cells confirm that these cells behave like bipotential progenitor cells and are able to differentiate into hepatocytes and cholangiocytes. ${ }^{30-34}$ Once activated and proliferating, it is proposed oval cells give rise to duct-like structures that arise from the periportal regions and spread into the liver acinus; several days after activation these ductlike structures change appearance, and transform into clusters of small basophilic hepatocytes and mature bile ducts.

Several researchers have isolated and immortalized hepatic progenitors. Generation of these bipotential cell lines have helped in studying the molecular mechanisms that regulate and drive activation and differentiation of progenitor cells. In 1998 Spagnoli and colleagues ${ }^{35}$ isolated and established the MMH (met murine hepatocyte) palmate cell line; immortalized bipotential liver precursor cells derived from explants of embryonic liver of transgenic mice expressing a constitutively active truncated human Met receptor (cyto-Met) under control of the human $\alpha 1$-antitrypsin transcription unit. ${ }^{36}$ Under appropriate culture conditions, Palmate cells are able to differentiate into hepatocytes and cholangiocytes, and are widely used to dissect the molecular pathways of hepatocyte formation. ${ }^{37}$ To date, many inbred mouse strains have been used to isolate and manipulate bipotential liver cells ${ }^{38,39}$ that possess progenitor properties in vitro and are in vivo and able to differentiate into hepatocytes and colonize diseased livers in mice. ${ }^{35,38,40,41}$

Due to significant differences in the anatomical structure of murine and human canals of Hering, oval cells are named liver precursor cells (LPCs) $)^{9,42}$ in human livers. LPCs proliferate in chronic liver diseases, such as alcoholic disease, steatohepatitis and viral hepatitis. However, LPCs are difficult to track and isolate because of the lack of a known definitive marker. Only recently, Schmelzer and colleagues ${ }^{43}$ have been able to isolate LPCs based on their expression of two surface markers, the epithelial cell adhesion molecule (EPCAM) and neural cell adhesion molecule (NCAM). LPCs have the ability to repopulate the liver in animal models.

According to our current understanding of liver regeneration, oval cells or LPCs represent a transient population of amplifying cells derived from normally quiescent true stem cells, which may reside in the biliary tree. ${ }^{8}$ In this context, the existence of a mesendodermal stem cell, with broader progenitor properties, capable of differentiation into hepatic parenchymal and non-parenchymal cells, has been hypothesized. .,44 $^{\text {. }}$

Purification of hepatic progenitor cells is often based on cell sorting, using putative oval cell specific surface markers. However, identification of oval cells is difficult because the surface and intracellular markers expressed by human and rat oval cells significantly differ from those expressed by mouse oval cells. Thus, rat oval cells express OV6, bile duct epithelium markers (CK-19) and hepatocyte markers (albumin, $\alpha$-fetoprotein [AFP]) and resemble hepatoblasts. ${ }^{2}$ The detailed characterization of oval cells in the rat has been done by Yovchev and colleagues ${ }^{7}$ (Figure 2). Rat oval cells express markers described mostly for hepatopoietic stem cells, such as c-kit, Sca-1, CD34 and Thy-1.1. ${ }^{45-47}$ While this fact would suggest that oval cells or true liver stem cells are replenished from BM progenitor cells, expression of Thy-1 by oval cells remains controversial. ${ }^{48-50}$ However, a recent study has demonstrated that Thy $-1^{+}$cells are located in rats in the "oval cell niche" and represent a subpopulation of activated mesenchymalepithelial cells that are distinct from resident stellate cells, myofibroblasts, or oval cells. ${ }^{51}$ Surprisingly, rat and mouse oval cells exhibit remarkable heterogeneity in expression of specific markers. ${ }^{52}$ In the search for specific precursor markers, it has been suggested that murine oval cells upregulate CK-19, AFP, albumin, Thy-1, CD34, delta-like protein (Dlk), EPCAM, TROP2, or the rat oval cell marker OV6. ${ }^{47,53-57}$ There is strong evidence independently demonstrated by several groups that mouse oval cells express CD133 and Sca-1. ${ }^{58-62}$ However, in contrast to rat oval cells, mouse oval cells do not always express these markers, and until recently could be identified by expression of only one intracellular marker A6. ${ }^{47,57}$ Hence, new antibodies against liver precursors may provide new markers of mouse oval cells (MIC1-1C3; OC2-1D11; OC2-2F3; OC2-1C6; OC2-2A6; OC2-6E10). Proliferating cells recognized by the new antibodies were located in ductal versus periductal areas, confirming the heterogenic nature of murine oval cell population ${ }^{63}$ and (Conigliaro and colleagues, unpublished observations) (Figure 2).

Many oval cell-specific markers are expressed intracellularly and cannot be used for isolation of viable cells. Moreover, expression of many reported markers, especially in rats and humans, is not restricted to the hepatic precursor cells, and many proposed markers are also upregulated by other cell types. Although oval cells can be isolated using a combination of several surface proteins, their ability to exhibit precursor properties is further tested in vitro and/or in vivo. Since there 


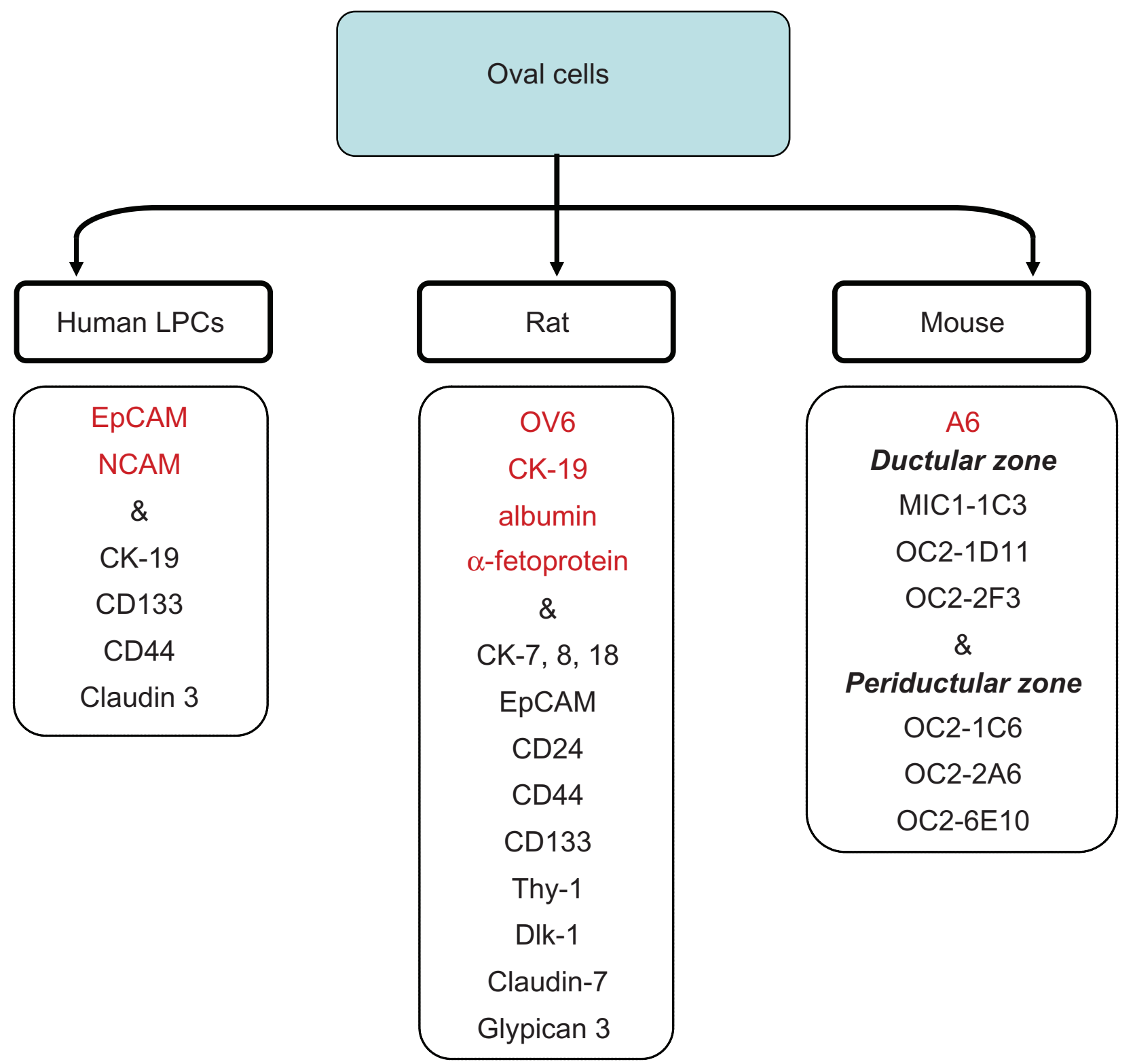

Figure 2 Markers of oval cells.

Notes: Intracellular and surface markers of oval cells in rats and mice differ from liver precursor cells (LPCs) in humans. The most compelling markers that are potentially useful for isolation of oval cells in different species, are shown.

is no agreement in the literature as to which combination of markers defines oval cells, an epithelial colony-forming assay has been developed to assess the precursor properties of isolated cells. By culturing highly enriched precursors with one cell in each well of 96-well plates, the nature of each cell is analyzed. Isolated multipotent precursors have to undergo in vitro expansion prior to differentiation analysis or being reintroduced back into the mouse (via adoptive transfer into the spleen). In vitro expanded precursors are tested for their ability to form colonies. For example, precursors (CD133+ $\mathrm{CK} 19^{+} \mathrm{CK}^{+} \mathrm{AFP}^{+} \mathrm{CD} 34^{+}$and $\mathrm{CD} 45^{-}$Ter1 $19^{-} \mathrm{c}^{-\mathrm{kit}^{-}}{ }^{-} \mathrm{Thy}-1^{-}$), isolated from adult livers of DDC-treated mice or untreated mice, exhibit distinct features of the multipotent population by forming two types of colonies in vitro, large mixed-lineage and small unilineage colonies.$^{61}$ Hence, cells from DDC-treated mice form both mixed- and unilineage colonies, which can give rise to hepatocytes and cholangiocytes when transferred into $\mathrm{FAH}^{-}$mice, while the cells from untreated mice formed only unilineage colonies. In addition, clonal expansion of single cells from the large mixed-lineage colonies has demonstrated that only $1 \%$ of the cells possessed true precursor properties. ${ }^{61}$ 
Oval cells represent a heterogeneous population. Three different scenarios can explain the heterogeneity of oval cells and their place in the hierarchy of liver stem cells: 1) Oval cells are a pool of hepatic progenitors undergoing different stages of differentiation. 2) Originating from the liver stem cells, oval cells themselves can follow different pathways of differentiation and give rise to distinct classes of oval cells with highly specialized functions, whose bi-potential activity is carried out by the cholangiocyte or hepatocyte progenitors. 3) Alternatively, oval cells are heterogeneous hepatic precursor cells that may originate from common hepatobiliary stem cells during differentiation upon the needs of hepatic tissue. ${ }^{9}$

\section{Liver stem cells}

Several reports have described the isolation of pluripotent cells from human fetal (human fetal liver multipotent precursor cell, [HFLMPC] $)^{64}$ and adult livers. ${ }^{65}$ HFLMPCs are classified as mesenchymal-epithelial transitional cells, which can be maintained in long-term culture in an undifferentiated state, but when properly treated differentiate into hepatocytes and cholangiocytes as well as into cells of several mesenchymal lineages (fat, cartilage, bone and endothelial cells). Human liver stem cells (HLSCs) are proposed to be a mesenchymal liver population with a partial commitment to hepatic cells. When cultured in the appropriate differentiation media, HLSCs can be induced to differentiate into mature hepatocytes, osteoblasts, or endothelial cells, showing a multilineage potentiality. Adult liver precursor cells appear in vivo in response to several types of pathological liver injury, especially when hepatocyte replication is impaired. These cells are histologically identified by the expression of cholangiocyte markers and proliferate in the portal area of the hepatic lobule. HLSCs may play an important role in liver regeneration by providing the self-renewing ability of bipotent primitive hepatic cells. ${ }^{61}$

The success rate of using the stem cells for restoring tissues depends on the ability to expand these cells in vitro and, in many cases, to direct their differentiation towards a specific cell lineage. ${ }^{66-69}$ Although in vitro expansion, growth and differentiation of isolated fetal stem cells does not necessarily drive their differentiation in vivo, it provides a unique system to study stem cell regulation, and to optimize conditions to direct endogenous regenerative potential towards a lineagespecific differentiation. In this regard, RLSCs (resident liver stem cells), a non- tumorigenic stable stem cell line obtained from fetal and neonatal murine livers, represent a useful tool to study stem cell biology. ${ }^{70}$ In their undifferentiated state,
RLSCs maintain a stem cell transcriptional profile and ability for self-renewal. Undifferentiated RLSCs co-express mesenchymal (eg, calponin 1), endodermal (eg, FoxA1 and aFP) and neuroectodermal (eg, nestin) stem cell markers together with several "stem" related genes (chromatin remodeling genes) crucial for the activation of stem cell genetic program. RLSCs differentiate into hepatocytes and cholangiocytes in vivo and in vitro and, when cultured under appropriate conditions, can give rise to mesenchymal and neuro-ectodermal cell lineages, such as osteoblasts/osteocytes, chondrocytes, astrocytes and neuronal cells. The ability to spontaneously differentiate into hepatocytes and the lack of albumin expression in an undifferentiated state, places RLSCs at the pre-hepatoblast/liver precursor cell hierarchy of liver stem cells. RLSCs were used $^{71}$ to study liver zonation, demonstrating for the first time a direct convergence of the canonical Wnt signaling on the HNF $4 \alpha$ driven transcription in RLSC derived periportal hepatocytes.

\section{BM contribution to liver regeneration}

Significant contribution of the BM to hepatocyte regeneration was originally established in the $F A H^{-\sim}$ mice, which develop liver failure in response to withdrawal of NTBC from their drinking water. Transplantation of total BM or myeloid cells into these mice results in fusion with the recipient hepatocytes, their clonal expansion, and reconstitution of normal liver mass. Despite this extraordinary ability of myeloid cells to rescue the phenotype of $F A H^{-/}$hepatocytes, such phenomenon was not (or very rarely) observed in response to other types of liver injury $\left(\mathrm{CCl}_{4}\right.$, bile duct ligation [BDL]), suggesting that hematopoietic cells have a limited contribution to hepatocyte population under physiological conditions or in response to injury. ${ }^{72,73}$ Meanwhile, there is some evidence that hematopoietic stem cells can contribute to replenishment of liver precursors or stem cells, since transplantation of highly purified hematopoietic stem cells resulted in generation of BM-derived ductular cells and hepatocytes. ${ }^{10,74,75}$ One can speculate that BM cells can replace oval cells or liver stem cells. In a recent study, Cho and colleagues have investigated the ability of purified hematopoietic stem cells (HSCs), mesenchymal stem cells (MSCs) and mononuclear cells to engraft and contribute to liver regeneration in response to injury. Of these populations, the MSCs transplanted group showed the highest engraftment rate and exhibited the utmost potential to differentiate into hepatocytes when co-cultured with injured liver cells. ${ }^{76}$

MSCs have been isolated from several sources, BM, cord blood, amniotic fluid, placenta and adipose tissue, and 
therefore, become a prime candidate for cell therapy. Several studies have demonstrated that MSCs isolated and expanded in vitro can be induced to differentiate into hepatocyte-like cells. ${ }^{77,78}$ However, only a low level of liver repopulation with the MSCs, derived from umbilical cord or adipose tissues, has been reported. In addition, differentiation of MSCs into hepatocytes requires both in vitro expansion and treatment with hepatogenic factor prior to transplantation. Several attempts have been made to treat liver pathologies with undifferentiated MSCs. Thus, human umbilical cord blood-derived cells transplanted into non-obese diabeticsevere combined immunodeficient (NOD-SCID) mice generated clusters of donor-derived hepatocytes in response to $\mathrm{CCl}_{4} \cdot{ }^{79}$ Although transplantation of MSCs often results in attenuation or improvement of liver disease, current studies have not provided a definitive proof for MSC differentiation into functional hepatocytes in vivo. ${ }^{14,77,79-81}$ Even more controversial is the role of MSCs in fibrosis. In response to fibrogenic liver injury $\left(\mathrm{CCl}_{4}, \mathrm{BDL}\right)$, both hematopoietic and MSCs have shown limited contribution to hepatocyte replenishment, but in turn, actively differentiated into fibrogenic cells. ${ }^{72,73,82}$ Moreover, Russo and colleagues have reported that MSCs directly differentiate into myofibroblasts in the damaged liver and facilitate fibrogenic processes. ${ }^{83}$ Therefore, it remains unclear if infusion of MSC fulfills the function or increases the risk from the transplantation therapy.

\section{Conclusion}

This review has summarized the potential contribution of intrahepatic and BM cells to liver regeneration. There are at least three sources of intrahepatic cells that are capable of differentiating into hepatocytes and cholangiocytes. In response to injury, hepatocytes themselves undergo activation, proliferate and differentiate into parenchymal cells. This process is the best documented and most understood, and currently provides the most therapeutic potential. Meanwhile, oval cells, heterogeneous liver precursor cells that most likely arise from the biliary tree, may contribute to newly formed hepatocytes and cholangiocytes. However, very little is known about the biology of oval cells, especially the conditions suitable to manipulate oval cell differentiation and expansion in vitro prior to reintroduction in vivo. Even less is known about "true" liver stem cells and their regenerative potential. Future studies are likely to further characterize intrahepatic stem cells, and new findings are needed to improve cell transplantation therapy.

\section{References}

1. Bataller R, Brenner DA. Liver fibrosis. J Clin Invest. 2005;115(2):209-218.

2. Shinozuka H, Lombardi B, Sell S, Iammarino RM. Early histological and functional alterations of ethionine liver carcinogenesis in rats fed a choline-deficient diet. Cancer Res. 1978;38(4):1092-1098.

3. Wang X, Foster M, Al-Dhalimy M, Lagasse E, Finegold M, Grompe M. The origin and liver repopulating capacity of murine oval cells. Proc Natl Acad Sci U S A. 2003;100 Suppl 1:11881-11888.

4. Dabeva MD, Shafritz DA. Activation, proliferation, and differentiation of progenitor cells into hepatocytes in the D-galactosamine model of liver regeneration. Am J Pathol. 1993;143(6):1606-1620.

5. Duncan AW, Dorrell C, Grompe M. Stem cells and liver regeneration. Gastroenterology. 2009;137(2):466-481.

6. Farber E. Similarities in the sequence of early histological changes induced in the liver of the rat by ethionine, 2-acetylamino-fluorene, and 3'-methyl-4dimethylaminoazobenzene. Cancer Res. 1956;16(2):142-148.

7. Yovchev MI, Grozdanov PN, Zhou H, Racherla H, Guha C, Dabeva MD. Identification of adult hepatic progenitor cells capable of repopulating injured rat liver. Hepatology. 2008;47(2):636-647.

8. Alison MR, Golding M, Sarraf CE, Edwards RJ, Lalani EN. Liver damage in the rat induces hepatocyte stem cells from biliary epithelial cells. Gastroenterology. 1996;110(4):1182-1190.

9. Theise ND, Saxena R, Portmann BC, Thung SN, Yee H, Chiriboga L, et al. The canals of Hering and hepatic stem cells in humans. Hepatology. 1999;30(6):1425-1433.

10. Lagasse E, Connors H, Al-Dhalimy M, Reitsma M, Dohse M, Osborne L, et al. Purified hematopoietic stem cells can differentiate into hepatocytes in vivo. Nat Med. 2000;6(11):1229-1234.

11. Petersen BE, Bowen WC, Patrene KD, Mars WM, Sullivan AK, Murase N, et al. Bone marrow as a potential source of hepatic oval cells. Science. 1999;284(5417):1168-1170.

12. Willenbring H, Bailey AS, Foster M, Akkari Y, Dorrell C, Olson S, et al. Myelomonocytic cells are sufficient for therapeutic cell fusion in liver. Nat Med. 2004;10(7):744-748.

13. Banas A, Teratani T, Yamamoto Y, Tokuhara M, Takeshita F, Osaki M, et al. IFATS collection: in vivo therapeutic potential of human adipose tissue mesenchymal stem cells after transplantation into mice with liver injury. Stem Cells. 2008;26(10):2705-2712.

14. Kuo TK, Hung SP, Chuang CH, Chen CT, Shih YR, Fang SC, et al. Stem cell therapy for liver disease: parameters governing the success of using bone marrow mesenchymal stem cells. Gastroenterology. 2008;134(7):2111-2121, 2121 e2111-e2113.

15. Cressman DE, Greenbaum LE, DeAngelis RA, Ciliberto G, Furth EE, Poli V, et al. Liver failure and defective hepatocyte regeneration in interleukin-6-deficient mice. Science. 1996;274(5291):1379-1383.

16. Hata S, Namae M, Nishina H. Liver development and regeneration: from laboratory study to clinical therapy. Dev Growth Differ. 2007;49(2): 163-170.

17. Michalopoulos GK, DeFrances MC. Liver regeneration. Science. 1997;276(5309):60-66.

18. Overturf K, Al-Dhalimy M, Ou CN, Finegold M, Grompe M. Serial transplantation reveals the stem-cell-like regenerative potential of adult mouse hepatocytes. Am J Pathol. 1997;151(5):1273-1280.

19. Overturf K, Al-Dhalimy M, Tanguay R, Brantly M, Ou CN, Finegold M, et al. Hepatocytes corrected by gene therapy are selected in vivo in a murine model of hereditary tyrosinaemia type I. Nat Genet. 1996;12(3):266-273.

20. Overturf K, Al-Dhalimy M, Finegold M, Grompe M. The repopulation potential of hepatocyte populations differing in size and prior mitotic expansion. Am J Pathol. 1999;155(6):2135-2143.

21. Dandri M, Burda MR, Zuckerman DM, Wursthorn K, Matschl U, Pollok JM, et al. Chronic infection with hepatitis B viruses and antiviral drug evaluation in uPA mice after liver repopulation with tupaia hepatocytes. J Hepatol. 2005;42(1):54-60.

22. Sandgren EP, Palmiter RD, Heckel JL, Daugherty CC, Brinster RL, Degen JL. Complete hepatic regeneration after somatic deletion of an albumin-plasminogen activator transgene. Cell. 1991;66(2):245-256. 
23. Traggiai E, Chicha L, Mazzucchelli L, Bronz L, Piffaretti JC, Lanzavecchia A, et al. Development of a human adaptive immune system in cord blood celltransplanted mice. Science. 2004;304(5667):104-107.

24. Haridass D, Yuan Q, Becker PD, Cantz T, Iken M, Rothe M, et al. Repopulation efficiencies of adult hepatocytes, fetal liver progenitor cells, and embryonic stem cell-derived hepatic cells in albuminpromoter-enhancer urokinase-type plasminogen activator mice. Am J Pathol. 2009;175(4):1483-1492.

25. Azuma H, Paulk N, Ranade A, Dorrell C, Al-Dhalimy M, Ellis E, et al. Robust expansion of human hepatocytes in $\mathrm{Fah}^{-/ /} / \mathrm{Rag}^{-/ /} / \mathrm{Il} 2 \mathrm{rg}^{-/}$mice. Nat Biotechnol. 2007;25(8):903-910.

26. Dhawan A, Mitry RR, Hughes RD. Hepatocyte transplantation for liverbased metabolic disorders. J Inherit Metab Dis. 2006;29(2-3):431-435.

27. Quaglia A, Lehec SC, Hughes RD, Mitry RR, Knisely AS, Devereaux S, et al. Liver after hepatocyte transplantation for liver-based metabolic disorders in children. Cell Transplant. 2008;17(12):1403-1414.

28. Falkowski O, An HJ, Ianus IA, Chiriboga L, Yee H, West AB, et al. Regeneration of hepatocyte 'buds' in cirrhosis from intrabiliary stem cells. J Hepatol. 2003;39(3):357-364.

29. Marshall A, Rushbrook S, Davies SE, Morris LS, Scott IS, Vowler SL, et al. Relation between hepatocyte $\mathrm{G} 1$ arrest, impaired hepatic regeneration, and fibrosis in chronic hepatitis C virus infection. Gastroenterology. 2005;128(1):33-42.

30. Evarts RP, Nagy P, Marsden E, Thorgeirsson SS. A precursor-product relationship exists between oval cells and hepatocytes in rat liver. Carcinogenesis. 1987;8(11):1737-1740.

31. Evarts RP, Nagy P, Nakatsukasa H, Marsden E, Thorgeirsson SS. In vivo differentiation of rat liver oval cells into hepatocytes. Cancer Res. 1989;49(6):1541-1547.

32. Fausto N. Liver regeneration and repair: hepatocytes, progenitor cells, and stem cells. Hepatology. 2004;39(6):1477-1487.

33. Newsome PN, Hussain MA, Theise ND. Hepatic oval cells: helping redefine a paradigm in stem cell biology. Curr Top Dev Biol. 2004;61:1-28.

34. Sell S. Is there a liver stem cell? Cancer Res. 1990;50(13):3811-3815.

35. Spagnoli FM, Amicone L, Tripodi M, Weiss MC. Identification of a bipotential precursor cell in hepatic cell lines derived from transgenic mice expressing cyto-Met in the liver. J Cell Biol. 1998;143(4):1101-1112.

36. Amicone L, Spagnoli FM, Spath G, Giordano S, Tommasini C, Bernardini S, et al. Transgenic expression in the liver of truncated Met blocks apoptosis and permits immortalization of hepatocytes. EMBO J. 1997;16(3):495-503.

37. Spagnoli FM, Cicchini C, Tripodi M, Weiss MC. Inhibition of MMH (Met murine hepatocyte) cell differentiation by TGF(beta) is abrogated by pre-treatment with the heritable differentiation effector FGF1. J Cell Sci. 2000;113(Pt 20):3639-3647.

38. Fougere-Deschatrette C, Imaizumi-Scherrer T, Strick-Marchand H, Morosan S, Charneau P, Kremsdorf D, et al. Plasticity of hepatic cell differentiation: bipotential adult mouse liver clonal cell lines competent to differentiate in vitro and in vivo. Stem Cells. 2006;24(9):2098-2109.

39. Strick-Marchand H, Weiss MC. Inducible differentiation and morphogenesis of bipotential liver cell lines from wild-type mouse embryos. Hepatology. 2002;36(4 Pt 1):794-804.

40. Shafritz DA, Oertel M, Menthena A, Nierhoff D, Dabeva MD. Liver stem cells and prospects for liver reconstitution by transplanted cells. Hepatology. 2006;43(2 Suppl 1):S89-S98.

41. Strick-Marchand H, Weiss MC. Embryonic liver cells and permanent lines as models for hepatocyte and bile duct cell differentiation. Mech Dev. 2003;120(1):89-98.

42. Roskams TA, Theise ND, Balabaud C, Bhagat G, Bhathal PS, Bioulac-Sage P, et al. Nomenclature of the finer branches of the biliary tree: canals, ductules, and ductular reactions in human livers. Hepatology. 2004;39(6):1739-1745.

43. Schmelzer E, Zhang L, Bruce A, Wauthier E, Ludlow J, Yao HL, et al. Human hepatic stem cells from fetal and postnatal donors. J Exp Med. 2007;204(8):1973-1987.

44. Rodaway A, Patient R. Mesendoderm an ancient germ layer? Cell. 2001; 105(2):169-172.
45. Fujio K, Evarts RP, Hu Z, Marsden ER, Thorgeirsson SS. Expression of stem cell factor and its receptor, c-kit, during liver regeneration from putative stem cells in adult rat. Lab Invest. 1994;70(4):511-516.

46. Hines IN, Kremer M, Isayama F, Perry AW, Milton RJ, Black AL, et al. Impaired liver regeneration and increased oval cell numbers following T cell-mediated hepatitis. Hepatology. 2007;46(1):229-241.

47. Petersen BE, Grossbard B, Hatch H, Pi L, Deng J, Scott EW. Mouse A6-positive hepatic oval cells also express several hematopoietic stem cell markers. Hepatology. 2003;37(3):632-640.

48. Dezso K, Jelnes P, Laszlo V, Baghy K, Bodor C, Paku S, et al. Thy-1 is expressed in hepatic myofibroblasts and not oval cells in stem cellmediated liver regeneration. Am J Pathol. 2007;171(5):1529-1537.

49. Dudas J, Mansuroglu T, Batusic D, Saile B, Ramadori G. Thy-1 is an in vivo and in vitro marker of liver myofibroblasts. Cell Tissue Res. 2007;329(3):503-514.

50. Petersen BE, Goff JP, Greenberger JS, Michalopoulos GK. Hepatic oval cells express the hematopoietic stem cell marker Thy-1 in the rat. Hepatology. 1998;27(2):433-445.

51. Yovchev MI, Zhang J, Neufeld DS, Grozdanov PN, Dabeva MD. Thymus cell antigen-1-expressing cells in the oval cell compartment. Hepatology. 2009;50(2):601-611.

52. Jelnes P, Santoni-Rugiu E, Rasmussen M, Friis SL, Nielsen JH, Tygstrup N, et al. Remarkable heterogeneity displayed by oval cells in rat and mouse models of stem cell-mediated liver regeneration. Hepatology. 2007;45(6):1462-1470.

53. Engelhardt NV, Factor VM, Yasova AK, Poltoranina VS, Baranov VN, Lasareva MN. Common antigens of mouse oval and biliary epithelial cells. Expression on newly formed hepatocytes. Differentiation. 1990;45(1):29-37.

54. Faktor VM, Engel'gardt NV, Iazova AK, Lazareva MN, Poltoranina VS, Rudinskaia TD. Common antigens of oval cells and cholangiocytes in the mouse. Their detection by using monoclonal antibodies. Ontogenez. 1990;21(6):625-632.

55. Jensen CH, Jauho EI, Santoni-Rugiu E, Holmskov U, Teisner B, Tygstrup N, et al. Transit-amplifying ductular (oval) cells and their hepatocytic progeny are characterized by a novel and distinctive expression of delta-like protein/preadipocyte factor $1 /$ fetal antigen 1 . Am J Pathol. 2004;164(4):1347-1359.

56. Okabe M, Tsukahara Y, Tanaka M, Suzuki K, Saito S, Kamiya Y, et al. Potential hepatic stem cells reside in EpCAM+ cells of normal and injured mouse liver. Development. 2009;136(11):1951-1960.

57. Tirnitz-Parker JE, Tonkin JN, Knight B, Olynyk JK, Yeoh GC. Isolation, culture and immortalisation of hepatic oval cells from adult mice fed a choline-deficient, ethionine-supplemented diet. Int J Biochem Cell Biol. 2007;39(12):2226-2239.

58. Clayton E, Forbes SJ. The isolation and in vitro expansion of hepatic Sca-1 progenitor cells. Biochem Biophys Res Commun. 2009;381(4):549-553.

59. Kisseleva T, Uchinami H, Feirt N, Quintana-Bustamante O, Segovia JC, Schwabe RF, et al. Bone marrow-derived fibrocytes participate in pathogenesis of liver fibrosis. J Hepatol. 2006;45(3):429-438.

60. Rountree CB, Barsky L, Ge S, Zhu J, Senadheera S, Crooks GM. A CD133-expressing murine liver oval cell population with bilineage potential. Stem Cells. 2007;25(10):2419-2429.

61. Suzuki A, Sekiya S, Onishi M, Oshima N, Kiyonari H, Nakauchi H, et al. Flow cytometric isolation and clonal identification of self-renewing bipotent hepatic progenitor cells in adult mouse liver. Hepatology. 2008;48(6):1964-1978.

62. Wright N, Samuelson L, Walkup MH, Chandrasekaran P, Gerber DA. Enrichment of a bipotent hepatic progenitor cell from naive adult liver tissue. Biochem Biophys Res Commun. 2008;366(2):367-372.

63. Dorrell C, Erker L, Lanxon-Cookson KM, Abraham SL, Victoroff T, Ro S, et al. Surface markers for the murine oval cell response. Hepatology. 2008;48(4):1282-1291.

64. Dan YY, Riehle KJ, Lazaro C, Teoh N, Haque J, Campbell JS, et al. Isolation of multipotent progenitor cells from human fetal liver capable of differentiating into liver and mesenchymal lineages. Proc Natl Acad Sci U S A. 2006;103(26):9912-9917. 
65. Herrera MB, Bruno S, Buttiglieri S, Tetta C, Gatti S, Deregibus MC, et al. Isolation and characterization of a stem cell population from adult human liver. Stem Cells. 2006;24(12):2840-2850.

66. Pellegrini G, Traverso CE, Franzi AT, Zingirian M, Cancedda R, De Luca M. Long-term restoration of damaged corneal surfaces with autologous cultivated corneal epithelium. Lancet. 1997;349(9057):990-993.

67. Rama P, Bonini S, Lambiase A, Golisano O, Paterna P, De Luca M, et al. Autologous fibrin-cultured limbal stem cells permanently restore the corneal surface of patients with total limbal stem cell deficiency. Transplantation. 2001 15;72(9):1478-1485.

68. Rochat A, Fernandez A, Vandromme M, Moles JP, Bouschet T, Carnac $\mathrm{G}$, et al. Insulin and wnt 1 pathways cooperate to induce reserve cell activation in differentiation and myotube hypertrophy. Mol Biol Cell. 2004;15(10):4544-4555.

69. Ruszczak Z, Schwartz RA. Modern aspects of wound healing: An update. Dermatol Surg. 2000;26(3):219-229.

70. Conigliaro A, Colletti M, Cicchini C, Guerra MT, Manfredini R, Zini R, et al. Isolation and characterization of a murine resident liver stem cell. Cell Death Differ. 2008;15(1):123-133.

71. Colletti M, Cicchini C, Conigliaro A, Santangelo L, Alonzi T, Pasquini E, et al. Convergence of Wnt signaling on the HNF4alphadriven transcription in controlling liver zonation. Gastroenterology. 2009;137(2):660-672.

72. Alison MR, Islam S, Lim S. Stem cells in liver regeneration, fibrosis and cancer: the good, the bad and the ugly. J Pathol. 2009;217(2):282-298.

73. Thorgeirsson SS, Grisham JW. Hematopoietic cells as hepatocyte stem cells: a critical review of the evidence. Hepatology. 2006;43(1):2-8.

74. Danet GH, Luongo JL, Butler G, Lu MM, Tenner AJ, Simon MC, et al. C1qRp defines a new human stem cell population with hematopoietic and hepatic potential. Proc Natl Acad Sci US A. 2002;99(16):10441-10445.

75. Wang X, Ge S, McNamara G, Hao QL, Crooks GM, Nolta JA. Albuminexpressing hepatocyte-like cells develop in the livers of immune-deficient mice that received transplants of highly purified human hematopoietic stem cells. Blood. 2003;101(10):4201-4208.
76. Cho KA, Ju SY, Cho SJ, Jung YJ, Woo SY, Seoh JY, et al. Mesenchymal stem cells showed the highest potential for the regeneration of injured liver tissue compared with other subpopulations of the bone marrow. Cell Biol Int. 2009;33(7):772-777.

77. Banas A, Teratani T, Yamamoto Y, Tokuhara M, Takeshita F, Osaki M, et al. Rapid hepatic fate specification of adipose-derived stem cells and their therapeutic potential for liver failure. J Gastroenterol Hepatol. 2009;24(1):70-77.

78. Mercer AE, Regan SL, Hirst CM, Graham EE, Antoine DJ, Benson CA, et al. Functional and toxicological consequences of metabolic bioactivation of methapyrilene via thiophene S-oxidation: Induction of cell defence, apoptosis and hepatic necrosis. Toxicol Appl Pharmacol. 2009;239(3):297-305

79. Sharma AD, Cantz T, Richter R, Eckert K, Henschler R, Wilkens L, et al. Human cord blood stem cells generate human cytokeratin 18-negative hepatocyte-like cells in injured mouse liver. Am J Pathol. 2005;167(2):555-564.

80. Abdel Aziz MT, Atta HM, Mahfouz S, Fouad HH, Roshdy NK, Ahmed $\mathrm{HH}$, et al. Therapeutic potential of bone marrow-derived mesenchymal stem cells on experimental liver fibrosis. Clin Biochem. 2007;40(12):893-899.

81. Sgodda M, Aurich H, Kleist S, Aurich I, Konig S, Dollinger MM, et al. Hepatocyte differentiation of mesenchymal stem cells from rat peritoneal adipose tissue in vitro and in vivo. Exp Cell Res. 2007;313(13):2875-2886.

82. Kisseleva T, Uchinami H, Feirt N, Quintana-Bustamante O, Segovia JC, Schwabe RF, et al. Bone marrow-derived fibrocytes participate in pathogenesis of liver fibrosis. J Hepatol. 2006;45(3):429-438.

83. Russo FP, Alison MR, Bigger BW, Amofah E, Florou A, Amin F, et al. The bone marrow functionally contributes to liver fibrosis. Gastroenterology. 2006;130(6):1807-1821.
Stem Cells and Cloning: Advances and Applications

\section{Publish your work in this journal}

Stem Cells and Cloning: Advances and Applications is an international, peer-reviewed, open access journal. Areas of interest in stem cell research include: Embryonic cell stems; Adult stem cells; Blastocysts; Cordblood stem cells; Stem cell transformation and culture; Therapeutic cloning; Umbilical cord blood and bone marrow cells; Laboratory,

\section{Dovepress}

animal and human therapeutic studies; Philosophical and ethical issues related to stem cell research. This journal is indexed on CAS. The manuscript management system is completely online and includes a quick and fair peer-review system. Visit http://www.dovepress.com/ testimonials.php to read real quotes from published authors. 